\title{
Performance analysis of solid oxide fuel cell and micro gas turbine top-level cycle
}

\author{
Qiao Run peng ${ }^{1, *}$, Liang Qian chao ${ }^{1}$, He Jun neng ${ }^{1}$, Yang Fan ${ }^{1}$ \\ ${ }^{1}$ College of Power Engineering, Naval University of Engineering, Wuhan, 430033, China.
}

\begin{abstract}
First, a simulation model of the SOFC-MGT top-level combined cycle was established through Matlab/Simulink, and then the effect of different methane flow rates on the performance of the stack and the SOFC-MGT system was analyzed. The research results show that with the increase of methane flow, the power of the stack and SOFC-MGT system gradually increases, but the efficiency of the SOFC-MGT system gradually decreases with the increase of methane flow.
\end{abstract}

\section{Introduction}

The efficiency of traditional gas turbines is limited by the "Carnot cycle", and the fuel utilization rate is only about $30 \%$. Most of the energy is lost in the form of heat. How to improve the efficiency of gas turbines has always been the focus of research. A fuel cell is a device that directly converts the chemical energy of hydrogen energy and other fuels into electrical energy. It has many advantages such as noiseless, high efficiency, and pollution-free $e^{[1,2]}$. Solid oxide fuel cell (SOFC) is a medium-high temperature fuel cell. Its stack working temperature is about $600{ }^{\circ} \mathrm{C} \sim 1000^{\circ} \mathrm{C}$, and the exhaust gas emission temperature is about $600^{\circ} \mathrm{C}$, and it has high quality can be reused ${ }^{[3]}$. Because fuel cells are not restricted by the "Carnot cycle", their energy utilization rate is much higher than that of traditional heat engines, usually between $60 \%$ and $80 \%$. Therefore, if the two can be effectively combined to form a fuel cell and gas turbine combined cycle system, the operating efficiency of the gas turbine will be greatly improved. The solid oxide fuel cell and micro gas turbine (SOFC-MGT) combined cycle has two main structures: one is the bottom cycle mode; the other is the top cycle mode.

$\mathrm{Lv}^{[4]}$ established an IT-SOFC-MGT top-level cycle simulation model to analyze the influence of water vapor content on system performance. Zhan ${ }^{[5]}$ established a dualreactor SOFC-MGT bottom cycle simulation model, and analyzed the impact of different SOFC reactor connection methods on system performance. $\mathrm{Zhu}^{[6]}$ established a SOFC-MGT top-level loop simulation model based on Matlab /Simulink software, and analyzed the impact of high back pressure $(1.7 \mathrm{~kg} / \mathrm{cm} 2)$ on system performance. Saisirirat ${ }^{[7]}$ used MATLAB simulation software to establish a detailed thermodynamic model of the SOFCGT hybrid system, and proposed two structures of the SOFC-GT hybrid cycle.

At present, scholars have conducted many researches on SOFC anode catalysts, electrolytes and other materials, but there are few studies on the combination of SOFCMGT. Therefore, this article combines the existing $1 \mathrm{~kW}$ SOFC in the laboratory to carry out the top-level circulation structure of SOFC-MGT. The analysis and research provide theoretical support for the industrial application of SOFC-MGT.

\section{Modular modelling}

\subsection{Assumptions}

In this paper, the following assumptions are made when modelling the SOFC-MGT dynamics.

-All gases are ideal

-The heat exchange between the system and the outside world is ignored

-The reforming reaction and the water-gas replacement reaction are in equilibrium

-The temperature, gas components and pressure in the system are uniformly distributed.

-The system is modelled using centralised parameters.

The SOFC-MGT top cycle structure is shown in Figure 1.

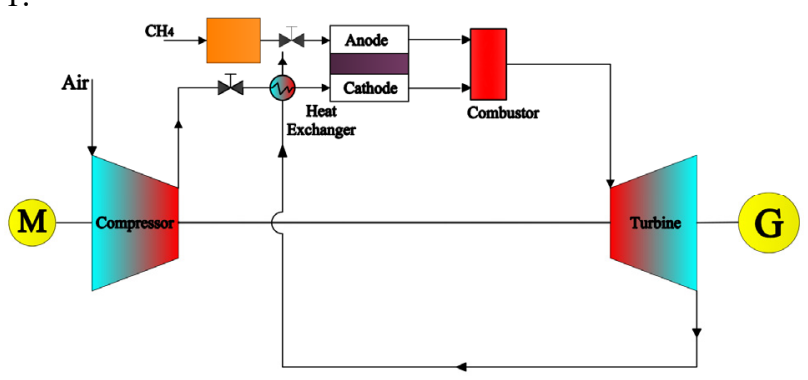

Fig.1 SOFC-MGT topping hybrid cycle

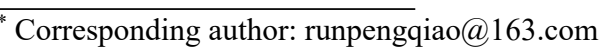




\subsection{Pre-reformer model}

In the pre-reformer, which mainly consists of the reforming reaction of methane and the water-gas replacement reaction, the chemical reaction equations are as follows ${ }^{[8]}$.

$$
\begin{aligned}
& \mathrm{CH}_{4}+\mathrm{H}_{2} \mathrm{O} \leftrightarrow \mathrm{CO}+3 \mathrm{H}_{2} \\
& \mathrm{CO}+\mathrm{H}_{2} \mathrm{O} \leftrightarrow \mathrm{CO}_{2}+\mathrm{H}_{2}
\end{aligned}
$$

From the equation for conservation of mass we get ${ }^{[5]}$ :

$$
\begin{gathered}
\frac{P_{1} V_{r e}}{R T_{1}} \frac{d x_{6, i}}{d t}=Q_{n 5, i}-Q_{n 6, i}+\bar{R}_{r e, i} \\
\left(i \in\left[\mathrm{CH}_{4}, \mathrm{CO}, \mathrm{CO}_{2}, \mathrm{H}_{2}, \mathrm{H}_{2} \mathrm{O}\right]\right) \\
\bar{R}_{r e}=\left[-r_{r e 1}, r_{r e 1}-r_{r e 2}, r_{r e 2}, 3 r_{r e 1}+r_{r e 2},-r_{r e 1}-r_{r e 2}\right]
\end{gathered}
$$

In the above equation, $P_{1}$ is the average pressure inside the pre-reformer, $V_{r e}$ is the volume of the prereformer, $T_{5}$ is the average temperature of the prereformer, $R$ is the universal gas constant $\left(8.314 \mathrm{~J} \cdot \mathrm{mol}^{-1} \cdot \mathrm{K}^{-1}\right), x_{2, i}$ is the molar mass fraction of the exit gas, $Q_{n 1, i}$ is the molar flow rate of the inlet gas, $Q_{n 2, i}$ is the molar flow rate of the exit gas, $\bar{R}_{r e, i}$ is the molar flow rate consumed by the reforming and water-gas replacement reactions of gas $i$ in the pre-reformer, $r_{r e 1}$ represents the reforming reaction rate of methane, $r_{r e 2}$ represents the replacement reaction rate of carbon monoxide.

Assuming that both the reforming and water-gas replacement reactions have reached equilibrium, the equilibrium constants can be expressed as ${ }^{[9]}$ respectively:

$$
\begin{aligned}
& K_{r}=\exp \left(A_{1} T_{5}^{4}+B_{1} T_{5}^{3}+C_{1} T_{5}^{2}+D_{1} T_{5}^{1}+E_{1}\right) \\
& K_{s}=\exp \left(A_{2} T_{5}^{4}+B_{2} T_{5}^{3}+C_{2} T_{5}^{2}+D_{2} T_{5}^{1}+E_{2}\right)
\end{aligned}
$$

In the above equations, $K_{r}$ and $K_{s}$ are the equilibrium constants for the reforming and water-gas replacement reactions respectively.

\subsection{Electrochemical model}

The actual voltage of a fuel cell monolith can be represented by the following equation.

$$
v_{f c}=E-\eta_{\text {ohmic }}-\eta_{\text {conc }}-\eta_{\text {act }, a}-\eta_{\text {act }, c}
$$

In the above equations, $E$ is the stack ideal reversible voltage, $\eta_{\text {ohmic }}$ is the ohmic polarization, $\eta_{\text {conc }}$ is the concentration difference polarization, $\eta_{a c t, a}$ is the anodic activation polarization, $\eta_{a c t, c}$ is the cathodic activation polarization. According to the Nernst equation, the ideal reversible voltage of the stack is expressed as ${ }^{[10]}$ :

$$
\begin{aligned}
& E=E^{0}+\frac{R T_{\text {cell }}}{2 F} \ln \left(\frac{p_{4, H_{2}} p_{5, O_{2}}^{0.5}}{p_{4, \mathrm{H}_{2} O}}\right) \\
& E^{0}=1.2723-2.7645 \times 10^{-4} T_{\text {cell }}
\end{aligned}
$$

In the above equations, $E^{0}$ is the standard electric potential, $p_{4, H_{2}}$ is the pressure of the hydrogen at the anode outlet, $p_{4, \mathrm{H}_{2} \mathrm{O}}$ is the pressure of the water at the anode outlet, $p_{5, O_{2}}$ is the pressure of the oxygen at the cathode inlet, $T_{\text {cell }}$ is the temperature of the stack.

\subsection{Temperature model}

According to the above assumptions, neglecting the heat exchange between the reactor and the outside world, the conservation of energy equation yields ${ }^{[11]}$ :

$$
\begin{aligned}
C_{\text {cell }} \frac{d T_{\text {cell }}}{d t}=Q_{n 3} \cdot \sum_{j}\left(X_{3, j} \cdot \bar{h}_{3, j}\right)+Q_{n 6} \cdot \sum_{i}\left(X_{6, i} \cdot \bar{h}_{6, i}\right)-Q_{n 4} \cdot \sum_{j}\left(X_{4, j} \cdot \bar{h}_{4, j}\right) \\
-Q_{n 7} \cdot \sum_{i}\left(X_{7, i} \cdot \bar{h}_{7, j}\right)-P_{\text {cell }}+\sum_{k} Q_{k}
\end{aligned}
$$

In the above equations, $i \in\left[\mathrm{CH}_{4}, \mathrm{CO}, \mathrm{CO}_{2}, \mathrm{H}_{2}, \mathrm{H}_{2} \mathrm{O}\right]$, $j \in\left[\mathrm{N}_{2}, \mathrm{O}_{2}\right], k=1,2,3, C_{\text {cell }}$ is the heat capacity of the reactor gas, $\bar{h}_{3, j}$ is the enthalpy of the SOFC cathode inlet gas $j, \bar{h}_{4, j}$ is the enthalpy of the cathode outlet gas, $Q_{n 3}$ is the molar flow rate of the cathode inlet gas, $Q_{n 4}$ is the molar flow rate of the cathode outlet gas, $\bar{h}_{6, i}$ is the enthalpy of the anode inlet gas, $\bar{h}_{7, i}$ 为 is the enthalpy of the anode outlet gas, $Q_{1}$ is the heat of reformation, $Q_{2}$ is the heat of water-gas replacement reaction, $Q_{3}$ is the heat of electrochemical reaction.

\subsection{Pressurised gas turbine model}

Compressor pressure ratio $\pi$ is:

$$
\pi=f_{1}\left(G_{1} \frac{p_{0} \sqrt{T_{1}}}{p_{1} \sqrt{T_{0}}}, n_{c} \frac{\sqrt{T_{0}}}{\sqrt{T_{1}}}\right)
$$

The compressor outlet temperature can be expressed as:

$$
T_{2}=T_{1}\left[1+\left(\pi^{m_{a}}-1\right) / \eta\right]
$$

\subsection{Turbine model}

The micro gas turbine uses a centripetal turbine, which has the advantages of simple structure, large enthalpy drop in a single stage and wide operating range ${ }^{[12]}$.

The turbine expansion ratio is:

$$
\varepsilon_{T}=f_{3}\left(\frac{G_{9} \sqrt{T_{9}}}{p_{9}}, \frac{n_{T}}{\sqrt{T_{9}}}\right)
$$

The turbine efficiency characteristics can be expressed as:

$$
\eta_{T}=f_{4}\left(\frac{G_{9} \sqrt{T_{9}}}{p_{9}}, \frac{n_{T}}{\sqrt{T_{9}}}\right)
$$

In the above equation, $G_{9}$ is turbine inlet flow, $p_{9}$ is turbine inlet pressure, $T_{9}$ is turbine inlet temperature, $\eta_{T}$ is turbine speed.

So far, the mathematical model of the SOFC-MGT combined cycle system has been established, and the simulation model of the new SOFC-MGT bottom cycle 
system has been obtained through Matlab/Simulink simulation.

\section{Performance analysis}

The laboratory has an existing $1 \mathrm{~kW}$ solid oxide fuel cell experimental system, as shown in Fig.2.

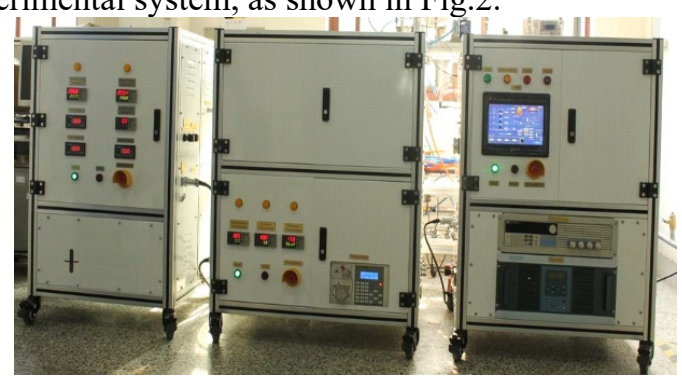

Fig.2 Solid oxide fuel cell experiment system

The set-up parameters for the SOFC-MGT hybrid power generation system model are shown in Table 1:

Tab.1 Initial conditions of SOFC-MGT system operation

\begin{tabular}{|c|c|c|}
\hline Parameters & Unit & Numerical values \\
\hline $\begin{array}{c}\text { Fuel import } \\
\text { composition } x_{1, i}\end{array}$ & - & $100 \% \mathrm{CH}_{4}$ \\
\hline Fuel inlet flow $Q_{n 1}$ & $\mathrm{~mol} \cdot \mathrm{s}^{-1}$ & $2.75 \times 10^{-3}$ \\
\hline $\begin{array}{c}\text { Air import } \\
\text { composition } x_{5, i}\end{array}$ & - & $79 \% \mathrm{~N}_{2}+21 \% \mathrm{O}_{2}$ \\
\hline Air inlet flow & $\mathrm{mol} \cdot \mathrm{s}^{-1}$ & $2.37 \times 10^{-2}$ \\
\hline $\begin{array}{c}\text { Fuel inlet pressure } \\
P_{1}\end{array}$ & $\mathrm{P}_{\mathrm{a}}$ & $1.013 \times 10^{5}$ \\
\hline Air inlet pressure $P_{5}$ & $\mathrm{P}_{\mathrm{a}}$ & $1.013 \times 10^{5}$ \\
\hline $\begin{array}{c}\text { Fuel inlet temperature } \\
T_{1}\end{array}$ & K & 298 \\
\hline $\begin{array}{l}\text { Air inlet temperature } \\
T_{5}\end{array}$ & K & 298 \\
\hline SOFC input current $i$ & A & 43 \\
\hline $\begin{array}{c}\text { Reactor pressure loss } \\
\sigma_{s t}\end{array}$ & - & $2 \%$ \\
\hline $\begin{array}{l}\text { Heat capacity of the } \\
\text { reactor } C_{s}\end{array}$ & $\mathrm{~J} \cdot \mathrm{K}^{-1}$ & 471 \\
\hline $\begin{array}{l}\text { Combustion chamber } \\
\text { pressure loss } \sigma_{b}\end{array}$ & - & $3 \%$ \\
\hline $\begin{array}{c}\text { Combustion chamber } \\
\text { efficiency } \eta_{b}\end{array}$ & - & $98 \%$ \\
\hline Number of batteries $\mathrm{N}$ & - & 30 \\
\hline $\begin{array}{c}\text { Compressor pressure } \\
\text { ratio } \varepsilon \\
\end{array}$ & - & 3.8 \\
\hline
\end{tabular}

Through simulation and experimental testing, the voltampere characteristic curve of SOFC is shown in Fig.3:

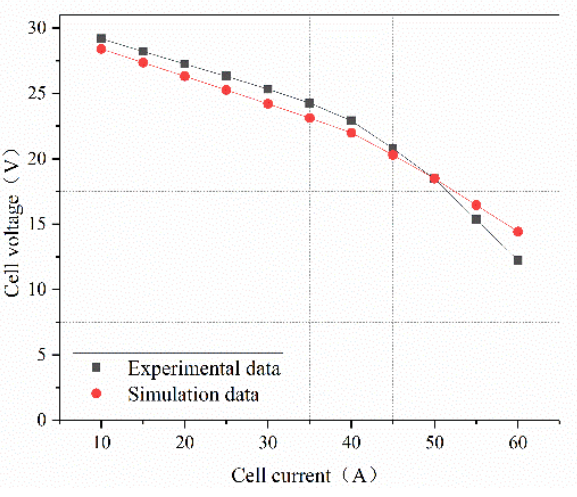

Fig.3 Volt-ampere characteristic curve of SOFC

As can be seen from the figure, the simulation model built in this paper is in good agreement with the experimental test data. When the output current is less than the rated output current of $43 \mathrm{~A}$, the maximum error between the simulation model and the experimental test data is $4.7 \%$.

Through simulation, the volt-ampere characteristic curve and fuel cell power characteristic curve of the fuel cell under different methane flow rates are obtained, as shown in Figs 4 and 5:

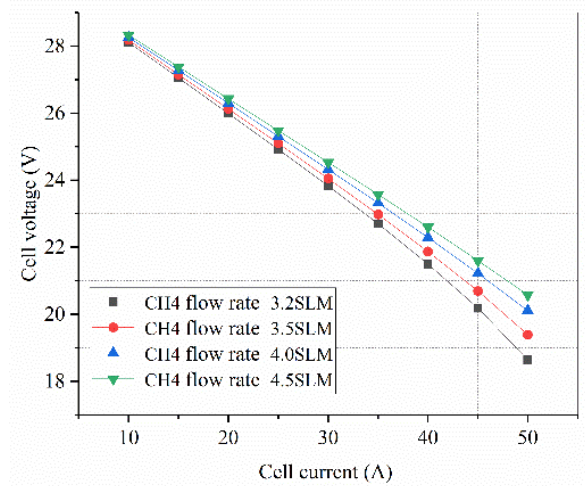

Fig.4 V-I characteristic cure of SOFC

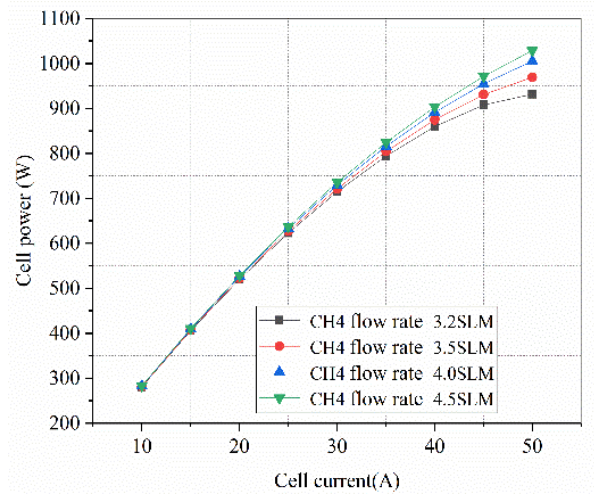

Fig.5 Power characteristic cure of SOFC

It can be seen from Fig. 4 and Fig. 5 that with the increase of methane flow, the output voltage and power of SOFC have increased. The larger the output current of SOFC, the increase of methane flow will greatly improve the output performance of the stack. However, the increase of methane flow will increase the internal pressure of the stack, which puts forward higher requirements on the 
sealing performance of the stack.

The system power characteristic curve of the SOFCMGT top-level cycle is shown in Fig.6 under different methane flow rates obtained through simulation.

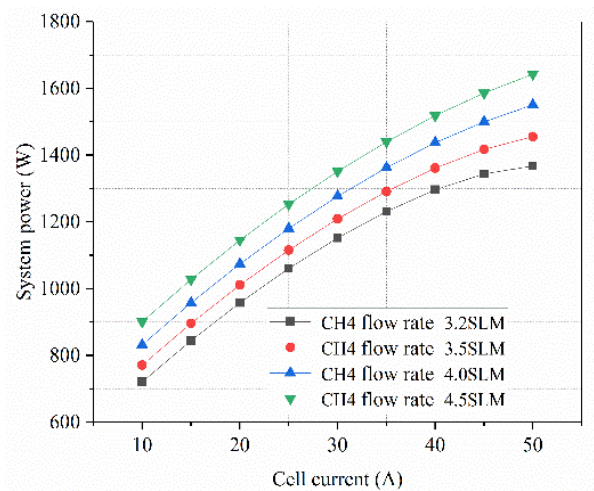

Fig.6 System power characteristic cure of SOFC-MGT

It can be seen from Fig.6 that with the increase of methane flow, the power of the SOFC-MGT system has increased. At the same time, the larger the output current of the stack, the greater the impact of the increase of methane flow on the output performance of the SOFCMGT system.

The system efficiency characteristic curve of the SOFC-MGT top-level cycle is shown in Fig.7 under different methane flow rates obtained through simulation.

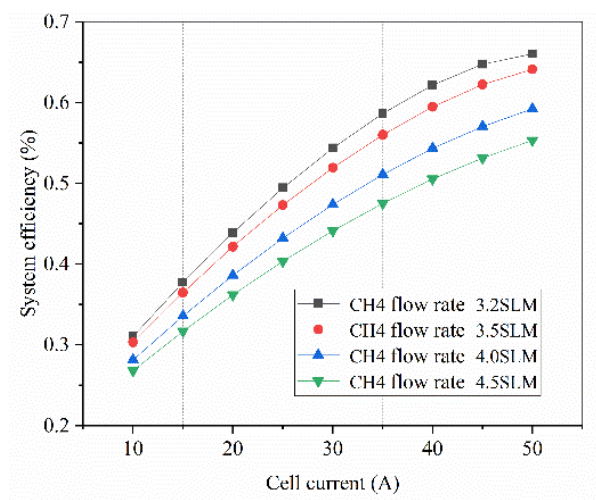

Fig.7 Efficiency characteristic cure of SOFC-MGT

It can be seen from Fig 7 that as the methane flow rate increases, the efficiency of the system gradually decreases. The greater the methane flow rate, the lower the efficiency of the system. This is because with the increase of methane flow, the maximum power of the stack gradually increases, and the maximum discharge current corresponding to the stack gradually increases, which makes the losses of the stack gradually increase, resulting in a gradual decrease in the efficiency of the system.

\section{Conclusions}

Through the simulation analysis of the SOFC-MGT combined cycle structure designed in this paper, the following conclusions are obtained:

- The SOFC-MGT simulation model established in this paper is correct, and the SOFC-MGT top-level combined cycle structure is feasible.

- As the methane flow rate increases, the output performance of the SOFC gradually increases. The larger the methane flow rate, the better the output performance.

- The greater the output current of the stack, the more obvious the effect of the increase in methane flow on the performance of the stack.

- With the increase of methane flow, the output performance of the SOFC-MGT system gradually increases, but the efficiency of the SOFC-MGT system gradually decreases.

\section{References}

1. Dai, A.N., Xu, L.F., Shui, A.Z. Research and progress on solid oxide fuel cells[J].Silicate Notification, 2015, 34(S1):234-238.

2. Costamagna, P., Magistri, L., Massardo, A.F. Design and part-load performance of a hybrid system based on a solid oxide fuel cell reactor and a micro gas turbine[J]. Journal of Power Sources, 2001, 96(2): 352-368.

3. Zhu, R.K., Liang, Q.C., Zhan, H.Y., et al. Modeling and simulation of direct internal reforming solid oxide fuel cell[J]. Ship Electric Technology, 2018 ,38(3): 12-17.

4. Lv, X.J., Lu, C.H., Geng, X.R., et al. Effect of water vapor on the performance of IT-SOFC/GT hybrid power system[J]. Journal of Engineering Thermophysics, 2016, 037(004):705-710.

5. Zhan, H.Y., Liang, Q.C., Zhu, R.K., et al. Study on the performance of fuel cell-gas turbine bottom cycle[J]. Journal of Ship Science and Technology, 2018, 40(15):76-80.

6. Zhu, R.K., Liang, Q.C., Yan, D.,et al. Study on modeling and simulation of combined power generation of solid oxide fuel cell and micro gas turbine[J].Journal of Ship Science and Technology, 2017,39(07):95-99.

7. Saisirirat, P. The Solid Oxide Fuel Cell (SOFC) and Gas Turbine (GT) Hybrid System Numerical Model[J]. Energy Procedia, 2015,79:845-850.

8. Fontell, E., Kivisaari, T., Christiansen, N.et al. Conceptual study of a $250 \mathrm{~kW}$ planar SOFC system for CHP application[J]. Journal of Power Sources, 2004.

9. Lu, Y., Schaefer, L. A solid oxide fuel cell system fed with hydrogen sulfide and natural gas[J].Journal of Power Sources, 2004 ,135(1-2):184-191.

10. Bove, R., Lunghi, P., Sammes, N.M.SOFC mathematic model for systems simulations. Part one: From a micro-detailed to macro-black-box model[J]. International Journal of Hydrogen Energy, 2005, 30(2):181-187.

11. Zhang, J. Characteristic analysis of combined cycle of solid oxide fuel cell and gas turbine [D]. North China Electric Power University, 2007.

12. Dai, G.S.Heat transfer [M].Beijing, Higher Education Press, 1999:120-140. 